\title{
The Impact of Concentration Toward Soccer Player Shooting Ability of Soccer School Batuang Taba Padang City
}

\author{
Tjung Hauw Sin ${ }^{1}$, Marjan Aprinanda ${ }^{1}$ \\ ${ }^{1}$ Universitas Negeri Padang \\ *Corresponding author, e-mail: tjunghauwsin@konselor.org
}

\begin{abstract}
The problem of this research was soccer player shooting ability of Soccer School Batuang Taba still low. It can be seen from the decreasing of their achievement that happened in Soccer School Batuang Taba. The aim of this study is to reveal the direct impact of Concentration, on Shooting ability of soccer player. This research method is quantitive by using Path Analysis approach. Population are 19 soccer players of U-15 Soccer School Batuang Taba. The sample technique is done by Proportionate Random Sampling, so the participants became 17 soccer players. The instrument was shooting ability test. Grid Concentration, exercise for measuring Concentration. Technique of data analysis used with Path Analysis. The result of research and data analysis showed that: Concentration has a direct and significant effect on Shooting ability of $12.25 \%$.
\end{abstract}

Keywords: Concentration, Shooting Ability of Soccer

How to Cite: Sin, T.H., Aprinanda.M., (2020). The Impact of Concentration Toward Soccer Player Shooting Ability of Soccer School Batuang Taba Padang City. International Journal of Research In Counseling and Education, 4 (1), 35-39

\section{Introduction}

The game of football is to enter the ball into the opponent's goal as much as possible and defend the goal itself from being broken in to obtain victor (Thoriq Al Mundiri, M., \& Widodo, 2019). To achieve the desired performance a soccer player must have good technical, physical, tactic, and mental skills. Syafruddin (2011: 22) ) which states that, "the ability of an athlete at a time of competition is influenced by physical, technical, tactic and mental factors". Next Tangkudung dan Puspitorini (Firmansyah, 2017) argued that the best achievement would only have been achieved if coaching could be carried out and focused on aspects of the whole training that included player personality, physical condition, technical skills, tactical skills, and player psychology. From the above quote we can know that the factors that affect a player's abilities are physical and mental factors which will also affect technical factors.

Football is a sport that requires good cooperation and it requires players to master good basic individual techniques. The basic technique is the most important component in soccer (Alexander, Wright, Taplinger, \& Fountain, 2020; Dawidowicz, Zysk, Figurska, Źróbek, \& Kotnarowska, 2020). The basic technique of football according to Luxbacher (2011: 71), explains that: "all activities that underlie activities so with this capital one can play well or practice directed". In football games there are 4 basic techniques, dribbling, passing, controlling, and shooting kicking the ball into the opponent's goal, a player must be able to kick well and on the desired target(Bettega et al., 2018; Masrudi, Ardilla, \& Wibowo, 2019). From the point of view of an attacker, the goal of football is to shoot at goal.

Among the basic techniques above, the most important technique is kicking the ball (shooting). Kicking the ball can be done in a ball at rest, the ball is rolling or the ball is floating in the air. However, the main purpose of kicking the ball (shooting) is to put the ball into the opponent's goal and to achieve that goal the ability to kick the goal is very instrumental (Ridwan, 2019). With the ability to kick into a good goal, a team will get a greater chance to score goals against the opponent and win. 
Also plays an important role in achieving the achievements of team sports such as football. In shooting ability is also influenced by other factors, one of which is factors originating from within the individual. As stated by (Effendi, 2016: 23) A player's performance is influenced by various psychological factors, both positive in terms of appearance being good, and negative in terms of appearance being bad, this is a psychological factor which is often called a psychological factor". Such as concentration, visualization and imagery abilities, behavior control (self-discipline) is believed to provide a positive role for players, football players in a training process to the point of a match. Concentration is a state in which a person's consciousness is fixed on a particular object in a certain time (Komarudin, 2013: 138). In soccer, to achieve a good target kick, a player must concentrate his concentration on the ball to be kicked towards the goal (Anggraini, 2020; Utama, 2020).

Of the many factors above, good concentration is a very important factor in shooting into the goal to get the victory in the match so as to achieve an expected achievement (Muttaqin, 2020). The fact is that in the field there are still many Soccer Schools whose achievements are not in line with expectations, especially the Batunag Taba Soccer School. However, despite continuous training and training the performance of the Batuang Taba Soccer School is still low and not as expected.

\section{Method}

The research method used in this research is an associative quantitative method, with a quantitative descriptive approach and a path analysis technique model. Descriptive quantitative research according toYusuf (2013: 61) aims to provide an in-depth overview of current events, or actual and meaningful problems. The Path Analysis according to Riduwan (2012:115) aims to analyze the pattern of relationships between variables with the aim to determine the direct or indirect influence of a set of independent (exogenous) variables on the dependent variable (endogenous). The purpose of this study was to determine the effect of both direct and indirect concentration on the ability to shoot soccer.

In this study, the population is all the Soccer School U-15 players Batuang Taba, amounting to 19 people. To determine the sample in this study, the Proportionate Random Sampling technique. Sugiyono (2011:124) argues that the sampling technique if the population has members / elements that are not stratified. Then the samples got amounted to 17 people.

\section{Results and Discussion}

Based on the results of calculations that have been made, it can be seen for the average of the concentration test which is 23.24 with a standard deviation of 3.77 . The minimum score for the concentration variable is 16 and the maximum score is 27.

Table 1. Concentration Assessment Norms

$\begin{array}{ccccc}\text { No } & \text { Interval } & \begin{array}{c}\text { Absolute Frequency } \\ \mathbf{( F a )}\end{array} & \begin{array}{c}\text { Relative Frequency } \\ \mathbf{( F r} \mathbf{\%})\end{array} & \text { Information } \\ \mathbf{1} & 21 \text { an above } & 13 & 76.47 & \text { Very good } \\ \mathbf{2} & 16-20 & 4 & 23.53 & \text { good } \\ \mathbf{3} & 11-15 & 0 & 0 & \text { Moderate } \\ \mathbf{4} & 6-10 & 0 & 0 & \text { Less } \\ \mathbf{5} & 5 \text { an Below } & 0 & 0 & \text { Very Less } \\ & \text { Total } & \mathbf{1 7} & \mathbf{1 0 0 . 0} & \end{array}$

Table 1 shows that of the 17 players who scored with a value of 21 and above as many as 13 people (76.47\%) with the Very Good category, who had a $16-20$ score of 4 people $(23.53 \%)$ with the Good category. The average score is 23.24 , so there are 17 players who have scores above the average or equal to the average (100\%) in the Very Good and Good categories.

While the average for variable shooting capability is 9.88 with a standard deviation of 2.20 . The minimum score of shooting ability variable is 7 and the maximum score is 14 . 
Table 2.Norms of Assessment Capabilities in Shooting Soccer

$\begin{array}{ccccc}\text { NO } & \text { Interval } & \begin{array}{c}\text { Absolute Frequency } \\ \mathbf{( F a )}\end{array} & \begin{array}{c}\text { Relative Frequency } \\ \mathbf{( F r} \%)\end{array} & \text { Information } \\ & & 2 & 11.76 & \text { Very Good } \\ \mathbf{1} & 13 \text { an above } & 5 & 29.41 & \text { good } \\ \mathbf{2} & 11-12 & 3 & 17.65 & \text { Moderate } \\ \mathbf{3} & 9-10 & 7 & 41.18 & \text { Less } \\ \mathbf{4} & 7-8 & 0 & 0 & \text { Very less } \\ \mathbf{5} & \text { 6 an below } & \mathbf{1 7} & \mathbf{1 0 0 . 0} & \\ & \text { Total } & \mathbf{1 7} & \end{array}$

Table 2 shows that of the 17 players who gained the ability to shoot soccer with a score of 13 and above 2 people $(11.76 \%)$ with the Very Good category, who had $11-12$ scores of 5 people (29.41\%) with the Good category, those who have 9-10 scores are 3 people (17.65\%) in the Medium category, and the players who have the ability to Shoot Soccer with a score of 7-8 are 7 people $(41.18 \%)$ with the Less category. The average value of 9.88 then there are 10 players who have scores above the average or equal to the average $(58.82 \%)$ with the category of Very good, good and moderate.

Table 3. Correlation Test
$\mathbf{R}$
Sig,
Decision
0.903
0.047
H0 rejected

Based on table 3 , the significance value $=0.047$ is smaller than the probability value $\alpha=0.05$, the value of $0.047<0.05$, in this case $\mathrm{Ha}$ is accepted and $\mathrm{Ho}$ is rejected, which means the coefficient of analysis is significant. Thus, Concentration has a direct effect on the Shooting Ability of Batuang Taba Football School (SSB) Players. From the results of this determination it can be concluded that the magnitude of the effect of the Concentration on the Shooting Ability of the Batuang Taba Football School (SSB) Player is $12.25 \%$. While the remaining $87.75 \%$ is influenced by other factors.

Concentration affects the ability to shoot because when a player is shooting requires a high concentration so that when the player is shooting at the goal is not affected by disturbances both from outside or inside the player (Nakano et al., 2020; Tan, Burns, Pan, \& Kong, 2020), meaning that the player who has a high concentration will be easy for him to do the shooting as desired. This applies to the findings of the research results. Utomo (2016: 74-78) stated that the level of concentration of students contributed positively to the success of getting good shooting skills. Komarudin (2013: 138) xplains that "concentration is the ability to focus attention on tasks that are not interrupted and are fulfilled by external and internal stimuli".

Concentration is one part of the psychological component that $d$ in sports, including football (Mulia, 2019). here are several important things in sports psychology in improving the ability of players, concentration. In soccer, a soccer player will not score well without the support of good concentration, because we need concentration to focus the mind and attention of a football player in directing the ball to the desired target. If the player has good concentration, he will be able to aim the ball well at the goal. And, someone who has low concentration usually can not do a good kick and far from the target (Setiawan, 2019).

\section{Conclusion}

Based on the results of the analysis and discussion above, it was concluded that Concentration had a direct and significant effect on the Shooting Ability of Batuang Taba Football School Players (SSB) by $12.25 \%$.

\section{References}

Alexander, H. B., Wright, C. J., Taplinger, D. H., \& Fountain, N. B. (2020). Incidence of seizure exacerbation and injury related to football participation in people with epilepsy. Epilepsy and Behavior, 104. https://doi.org/10.1016/j.yebeh.2019.106888 
Anggraini, M. (2020). Penerapan Four Goal Games Terhadap Hasil Belajar Passing Sepakbola. Jurnal Pendidikan Olahraga Dan Kesehatan, 7(3).

Bettega, O., Scaglia, A., Nascimento, J., Ibáñez, S., \& Galatti, L. (2018). Teaching tactics and technique in football: Conceptions of basic categories coaches . Retos, (33), 112-117. Retrieved from https://www.scopus.com/inward/record.uri?eid=2-s2.0-

85045518254\&partnerID=40\&md5=18102420288f32ec0fec566dd7327ff9

Dawidowicz, A., Zysk, E., Figurska, M., Źróbek, S., \& Kotnarowska, M. (2020). The methodology of identifying active aging places in the city - Practical application. Cities, 98. https://doi.org/10.1016/j.cities.2019.102575

Effendi, H. (2016). Peranan Psikologi Olahraga Dalam Meningkatkan Prestasi Atlet. Nusantara. Jurnal Ilmu Pengetahuan Sosial., 1.

Firmansyah, H. (2017). Hubungan Antara Aspek Fisik Dan Psikologis Studi Pada Atlet Senam Artistik Putra Jawa Barat. HUMANITAS, 14(1), 78-89.

Komarudin, \& Y. H. (2013). Psikologi Olahraga. Bandung: Remaja Rosda Karya.

Luxbacher, J. A. (2011). Sepakbola (Langkah-Langkah Menuju Sukses) Edisi Kedua. Jakarta: Raja Grafindo Persada.

Masrudi, M. I., Ardilla, F., \& Wibowo, I. K. (2019). Fusion of Feedforward and Feedback Control Using Fuzzy for Active Handling and Dribbling System in MSL Robot Soccer. In M. F.D., A. I., B. F.N.C., Z. A., \& A. M.E. (Eds.), 20th International Electronics Symposium on Engineering Technology and Applications, IES-ETA 2018 (pp. 216-223). Department of Informatics and Computer Engineering, Politeknik Elektronika Negeri Surabaya (PENS), Kampus PENS, Jalan Raya ITS Sukolilo, Surabaya, 60111, Indonesia: Institute of Electrical and Electronics Engineers Inc. https://doi.org/10.1109/ELECSYM.2018.8615562

Mulia, R. (2019). Hubungan Tingkat Konsentrasi dengan Kemampuan Shooting pada Pemain Sepakbola Ps. Lambhuk Tahun 2018. ETD Unsyiah.

Muttaqin, A. F. (2020). Pengaruh Media Pembelajaran terhadap Hasil Belajar Lay Up dalam Permainan Bola Basket pada Kelas Viii Smpn 2 Tanggulangin. Jurnal Pendidikan Olahraga Dan Kesehatan, 7(3).

Nakano, N., Inaba, Y., Fukashiro, S., \& Yoshioka, S. (2020). Basketball players minimize the effect of motor noise by using near-minimum release speed in free-throw shooting. Human Movement Science, 70. https://doi.org/10.1016/j.humov.2020.102583

Riduwan, \& E. K. (2012). Cara mengunakan dan memakai Path Analysis. Bandung: Alvabeta.

Ridwan, M. (2019). Kekuatan Otot Tungkai, Koordinasi Mata-Kaki dan Keseimbangan Berhubungan dengan Kemampuan Shooting Sepakbola. Jurnal Patriot, 2(4), 749-761.

Setiawan, H. (2019). Peningkatkan Keterampilan Shooting Sepakbola Melalui Modifikasi Alat. KHhazanah Pendidikan, 12(1).

Sugiyono. (2011). Metode Penelitian Kuantitatif Kualitatif dan R\&D. Bandung: Elfabeta.

Syafruddin. (2011). Ilmu Kepelatihan Olahraga Teori dan Aplikasinya dalam Pembinaan Olahraga. Padang: Fakultas Ilmu Keolahragaan Universitas Negeri Padang.

Tan, Z. S., Burns, S. F., Pan, J. W., \& Kong, P. W. (2020). Effect of caffeine ingestion on free-throw performance in college basketball players. Journal of Exercise Science and Fitness, 18(2), 62-67. https://doi.org/10.1016/j.jesf.2019.12.002 
Thoriq Al Mundiri, M., \& Widodo, A. (2019). Pengembangan Model Latihan Bertahan Berbasis Analisis Video Pertandingan Juventus Fc Vs Tottenham Hotspur Fc dalam Pertandingan 16 Besar Liga Champions 2018. Jurnal Kesehatan Olahraga, 7(2).

Utama, A. Z. (2020). Pengaruh latihan kelincahan dan kelentukan terhadap keterampilan dribbling sepakbola SSB PAS-ITN Kabupaten Malang. SKRIPSI Mahasiswa UM.

Utomo, E. B. (2016). Kontribusi Tingkat Konsentrasi terhadap ketepatan Shooting Futsal. Jurnal Kesehatan Olahraga, 7(3), 74-80.

Yusuf, A. M. (2013). Metode Penelitian Kuantitatif, Kualitatif, dan Penelitian Gabungan. Padang: UNP Press. 